\title{
DIRECT HYDROCRACKING OF OXIDIZED BIO-OIL TO HYDROCARBONS
}

\author{
Sathish K. Tanneru and Philip H. Steele* \\ Department of Sustainable Bioproducts, Mississippi State University, Mississippi State, \\ Starkville, MS, 39762 \\ *Corresponding author: psteele@cfr.msstate.edu
}

\begin{abstract}
\end{abstract}
Hydrodeoxygenation is considered a promising technology to convert bio-oils to liquid transportation fuels. Recently we tested a hydrodeoxygenation method to convert oxidized biooil to increase liquid fuel yield, reduce char and reduce required hydrogen. In this current study we tested direct hydrocracking of the oxidized bio-oil to produce high-energy liquid hydrocarbons. We tested various reaction conditions (reaction temperature, hydrogen pressure, time and catalyst type) on the hydrocracking of the oxidized bio-oil. Direct hydrocracking of the oxidized bio-oil produced $36.6 \%$ higher hydrocarbons yield compared to direct hydrocracking of the raw bio-oil. The hydrocarbons mixture produced had a higher heating value (HHV) of 43.6 $\mathrm{MJ} / \mathrm{kg}$. The oxygen content and acid value were $0.5 \mathrm{wt} \%$ and $0.3 \mathrm{mg} \mathrm{KOH} / \mathrm{g}$, respectively. Density and viscosity were considerably low at $0.9 \mathrm{~g} / \mathrm{ml}$ and $1.8 \mathrm{cSt}$, respectively. $\mathrm{pH}$ value was 8.4. The hydrocarbon mixture was also analyzed by GC-MS, FTIR, NMR and DHA.

Keywords: Bio-oil, oxidation, hydrodeoxygenation, hydrocracking, HHV

\section{Introduction}

Increasing energy demand and the approach of peak production of petroleum supply have led the world to search for renewable, sustainable and environmentally benign alternative fuels. According to the Renewable Fuels Standard the present use of renewable fuels is 14 billion gallons per year (BGY) and is projected to use 36 BGY by 2022 [1]. Woody biomass is one of 
24 the most important renewable energy resources for the production of sustainable liquid fuels [2].

25 Biomass as a renewable energy source will reduce dependency on conventional fuels and

26 provides significant environmental advantages over fossil fuels. It is greenhouse gas neutral

27 because the $\mathrm{CO}_{2}$ emitted from the bio-fuels from which it is produced is recycled by

28 photosynthesis $[3,4]$. The availability of biomass in the world is 220 billion dry tons per year and

29 is the world's largest and most sustainable energy resource. These advantages make biomass a 30 potential alternative energy source for fossil fuels.

31 Fast pyrolysis is one of the most promising thermal decomposition methods to produce

32 pyrolysis oil (bio-oil) from lignocellulosic biomass [5]. Bio-oil produced from fast pyrolysis is a

33 dark brown liquid with a pungent phenolic odor; its chemical properties vary with feedstock type

34 and applied pyrolysis conditions [6]. As a fuel raw bio-oil has environmental advantages when

35 compared to fossil fuels but its complex chemical composition contains numerous oxygenates

36 such as carboxylic acids, aldehydes, ketones, alcohols, phenols and phenolic derivatives and

37 others [7-9]. The high percentage of oxygenated compounds present in raw bio-oils results in a

40 to $50 \%$ oxygen content which causes negative properties such as low energy density, high

39 acidity, immiscibility with petroleum products and viscosity increase with heating or over time $[5,10]$. It is universally agreed that bio-oils need to be significantly upgraded to allow their use to

41 fuel internal combustion engines [4, 11, 12].

42 Hydrodeoxygenation (HDO) is a widely practiced method to produce hydrocarbons from 43 pyrolysis oil [12-18]. Elliot and Baker (1989) [19] in U.S. Patent No. 4,795,841 disclosed a 44 method to prevent bio-oil from polymerizing by practicing what they termed "mild 45 hydrotreating" which consisted of utilizing a mild temperature regime in the range of 250 to 300 $46{ }^{\circ} \mathrm{C}$ in the presence of hydrogen and a hydrotreating catalyst. It has now become traditional to 
47 apply this method to partially upgrade bio-oil prior to application of hydrocracking as a second 48 stage to produce pure hydrocarbons. The utilization of a mild hydrotreating prevents 49 polymerization of the bio-oil that would occur if direct hydrocracking were applied without this 50 step $[12,18,20,21]$.

51 Many researchers have practiced application of the hydrotreating step at mild temperatures 52 (200-400 $\left.{ }^{\circ} \mathrm{C}\right)$ to prevent bio-oil polymerization; typical hydrogen pressure applied for 53 hydrotreating ranges from 4 to $10 \mathrm{MPa}$ in the presence of a heterogeneous hydrotreating catalyst. 54 The hydrocracking step is performed at more severe temperatures $\left(300-500{ }^{\circ} \mathrm{C}\right)$ and also at 55 higher pressures ranging from 10 to $20 \mathrm{MPa}$ in the presence of a heterogeneous hydrocracking 56 catalyst [15, 19, 22-24]. The general HDO reaction is shown as Scheme 1 [25].

Zhang et al. (2003) studied the mechanism and reaction conditions of bio-oil deoxygenation 59 in the presence of a sulfide cobalt molybdate catalyst and with addition of the hydrogen donor tetralin. The effects of reaction time, temperature, and hydrogen pressure on the single-stage

61 deoxygenation were examined. Researchers performed several reactions by varying temperature 62 and reaction times. They concluded that, as the temperature and reaction time increased, the 63 deoxygenation of bio-oil also increased. However, higher temperature and longer reaction times 64 also led to coke formation and catalyst deactivation. They also reported that hydrogen pressure 65 had a significant effect on results by increasing the deoxygenation of the bio-oil [22].

Wildschut et al. (2009) performed a two-stage HDO by which a hydrotreating $1^{\text {st }}$-stage was 67 followed by a hydrocracking $2^{\text {nd }}$-stage on bio-oil with noble metal catalysts. $\mathrm{Ru} / \mathrm{Al}_{2} \mathrm{O}_{3}, \mathrm{Ru} / \mathrm{C}$, $68 \mathrm{Ru} / \mathrm{TiO}_{2}, \mathrm{Pd} / \mathrm{C}, \mathrm{Pt} / \mathrm{C}, \mathrm{CoMo} / \mathrm{Al} 2 \mathrm{O} 3$, and sulfide $\mathrm{NiMo} / \mathrm{Al}_{2} \mathrm{O}_{3}$ were tested. The hydrotreating $1^{\text {st }}$ 69 stage was applied to bio-oil at a temperature of $250{ }^{\circ} \mathrm{C}$ and 100 bar hydrogen pressure and was 
70 followed by $2^{\text {nd }}$-stage hydrocracking at a temperature of $350{ }^{\circ} \mathrm{C}$ and 200 bar hydrogen pressure

71 for $4 \mathrm{~h}$ in an autoclave reactor. The $1^{\text {st- }}$ stage mildly deoxygenated hydrocarbon yields ranged

72 between 21 to $58 \mathrm{wt} \%$ and the oxygen content ranged between 18.5 to $26.5 \mathrm{wt} \%$. $\mathrm{Pd} / \mathrm{C}$ was

73 found to be the best choice for the $1^{\text {st }}$-stage hydrotreating process. The $2^{\text {nd }}$-stage hydrocracking

74 process liquid hydrocarbon oil yields ranged between 25 to $65 \mathrm{wt} \%$ and oxygen content ranged

75 between 6 and $11 \mathrm{wt} \%$ [20].

76 Wildschut et al. (2010) performed a study to gain insight into catalyst stability of ruthenium

77 on alumina $\left(\mathrm{Ru} / \mathrm{Al}_{2} \mathrm{O}_{3}\right)$, ruthenium on carbon $(\mathrm{Ru} / \mathrm{C})$ and platinum on carbon $(\mathrm{Pt} / \mathrm{C})$ catalysts for

78 the direct $\mathrm{HDO}$ by single-stage treatment of fast pyrolysis oil at $350{ }^{\circ} \mathrm{C}$ and 200 bar hydrogen

79 pressure for $4 \mathrm{~h}$ in a batch reactor set-up. Researchers concluded that ruthenium or platinum on

80 carbon catalysts provided equally superior yield and deoxygenation compared to the $\mathrm{Pt} / \mathrm{C}$ and

$81 \mathrm{Ru} / \mathrm{Al}_{2} \mathrm{O}_{3}$ catalysts. The highest upgraded oil yield obtained with $\mathrm{Ru} / \mathrm{C}$ was 65 wt $\%$ with

82 reduction of oxygen content from 40 to $6 \mathrm{wt} \%$. They also concluded that prolonged reaction time

83 led to decreased end-product yields and increased levels of oxygen content. Researchers

84 hypothesized that these results may have been due to the gasification of the products and

85 depolymerisation of solids. Complete deoxygenation of bio-oil by the applied method and

86 catalysts was not achieved due to the mild temperature conditions applied in the single state of

87 direct HDO applied [15].

$88 \quad$ McCall et al. (2012) in U.S. Patent No. 8,329,969, B2 disclosed a method to produce fuel and 89 fuel-blending components from biomass-derived pyrolysis oil. The process included the 90 production of hydrocarbons by a two-stage deoxygenation of mixed-wood pyrolysis oil. In an

91 example, researchers performed partial deoxygenation by pumping the pyrolysis oil through a 92 fixed bed reactor loaded with a hydrotreating catalyst at a mild temperature between $250-340{ }^{\circ} \mathrm{C}$ 
93 and pressurized hydrogen at 1950-2010 psi. Once the hydrotreating was completed the oil

94 fraction was isolated after separation and removal of water generated in the reaction. This

95 partially deoxygenated oil was then fully deoxygenated by pumping through a full

96 deoxygenation zone loaded with a hydrocracking catalyst and with the application of a more

97 severe temperature between $405-407{ }^{\circ} \mathrm{C}$ in the presence of pressurized hydrogen between 1510 $98 \quad 1525$ psi [21].

$99 \mathrm{Xu}$ et al. (2013) investigated two-stage catalytic HDO of fast pyrolysis oil to produce 100 hydrocarbon liquid fuels. Researchers employed a first mild hydrotreating step to bio-oil to 101 overcome coke formation using $\mathrm{Ru} / \mathrm{C}$ noble catalyst at a temperature of $300{ }^{\circ} \mathrm{C}$ and $1500 \mathrm{psig}$ 102 hydrogen pressure. The hydrocracking step employed a more severe temperature of $400{ }^{\circ} \mathrm{C}$ and 1031950 psig pressurized hydrogen using traditional $\mathrm{NiMo} / \mathrm{Al}_{2} \mathrm{O}_{3}$ catalyst. Researchers reported that 104 coke formation was effectively eliminated. The oxygen content of the hydrocarbon fuel 105 decreased from $48.0 \mathrm{wt} \%$ rigidly contained in the bio-oil to $0.5 \mathrm{wt} \%$. The HHV increased from 10617.0 to $46.0 \mathrm{MJ} / \mathrm{kg}[18]$.

107 Tanneru et al. (2014) developed a method to produce a fuel with increased yield, reduced 108 coke formation and water content, and lower hydrogen pressure with lower hydrogen utilization 109 following a two-stage hydrodeoxygenation (hydrotreating followed by hydrocracking) of 110 oxidized bio-oil. Researchers applied a $1^{\text {st }}$-stage hydrotreating at a temperature of $360{ }^{\circ} \mathrm{C}$ and 111 under 800 psig hydrogen pressure. The $2^{\text {nd }}$-stage hydrocracking of the hydrotreated product was 112 performed at a higher temperature of $425^{\circ} \mathrm{C}$ and under 1400 psig hydrogen pressure [17].

113 The objective of our current study was to produce liquid hydrocarbons by direct 114 hydrocracking of oxidized bio-oil. The effect of the hydrocracking conditions of reaction time, 
115 temperature, hydrogen pressure and catalyst type were tested to determine the most effective 116 reaction conditions.

\section{Materials and methods}

118 Nickel on silica-alumina $(66 \pm 5 \% \mathrm{Ni})$ catalyst powder was obtained from Alfa Aesar. Ru/C $119(5 \%, \mathrm{Ru}), \mathrm{Ru} / \mathrm{Al}_{2} \mathrm{O}_{3}(5 \%, \mathrm{Ru})$ and $\mathrm{Cu}(\mathrm{II}) \mathrm{O}$ catalyst powder were obtained from Sigma-Aldrich. $120 \mathrm{Ni} / \mathrm{SiO} 2-\mathrm{Al} 2 \mathrm{O} 3+\mathrm{CuO}, \mathrm{Ru} / \mathrm{C}+\mathrm{CuO}$ and $\mathrm{Ru} / \mathrm{Al} 2 \mathrm{O} 3+\mathrm{CuO}$ catalysts were prepared by phydical 121 mixing method. Bio-oil required for this research was produced from bark-free loblolly pine 122 wood chips with a size of 1-3 mm and moisture content of 8-10\% on dry-weight basis. Raw bio123 oil (RBO) was produced by the fast pyrolysis process performed at a temperature of $450{ }^{\circ} \mathrm{C}$ with

124 nitrogen carrier gas at a rate of $7-\mathrm{kg} / \mathrm{h}$ with the auger-feed pyrolysis reactor located in the 125 Department of Sustainable Bioproducts, Mississippi State University (MSU). The MSU auger 126 fast pyrolyzer produced 60-65 wt\% of liquid product, $10-15 \%$ of non-condensable gases and 20$12725 \%$ of char on a dry biomass weight basis.

\subsection{RBO oxidation pretreatment}

Bio-oil pretreatment by oxidation was performed in a stainless steel, high-pressure batch 130 autoclave reactor equipped with an overhead magnetic stirrer, a pressure indicator with a maximum capacity of 5000 psig and a thermocouple for temperature monitoring in the range of

$132 \quad 0-500{ }^{\circ} \mathrm{C}$. The autoclave was equipped with an electrical heating and cooling system to control 133 the temperature inside the reactor. The proprietary oxidative pretreatment applied significantly 134 changed the RBO chemical composition. All pretreatment experiments were performed by 135 adopting the procedure followed in Tanneru et al. (2014) [17]. Briefly, this procedure utilized a 136 combination of both oxone (potassium peroxymonosulfate) and hydrogen peroxide to oxidize 
$137 \mathrm{RBO}$ at room temperature and without pressure. In the remainder of this paper, for clarity of

understanding, the pretreated RBO by oxidation will be termed oxidized product.

\subsection{Hydrocracking of oxidized product}

All hydrocracking experiments were performed in the same Parr batch autoclave described in section 2.1. Following the oxidative pretreatment of bio-oil direct hydrocracking was performed at temperatures of 375,400 and $425{ }^{\circ} \mathrm{C}$. The hydrogen pressures applied were 1000, 1200 and 1400 psig. Reaction times tested were $2.0,2.5$ and $3.0 \mathrm{~h}$. The catalyst types tested were $\mathrm{Ni} / \mathrm{SiO}_{2}-$ $\mathrm{Al}_{2} \mathrm{O}_{3}, \mathrm{Ni} / \mathrm{SiO}_{2}-\mathrm{Al}_{2} \mathrm{O}_{3}+\mathrm{CuO}, \mathrm{Ru} / \mathrm{C}+\mathrm{CuO}$ and $\mathrm{Ru} / \mathrm{Al}_{2} \mathrm{O}_{3}+\mathrm{CuO}$. All catalysts were prepared by physical mixing method and catalysts were directly used without any further activation or purification. The best reaction condition was chosen based on the quality of the physical properties and yield of the hydrocarbons produced by hydrocracking the oxidized bio-oil. For the best reaction condition the hydrocracking of $\mathrm{RBO}$ was also performed as a control to compare hydrocracked RBO hydrocarbon properties and yield to those of the hydrocracked product produced from the oxidized product.

In each experiment, once the reaction was complete, the liquid products were cooled in the reactor. The liquid product was collected in test tubes and centrifuged for $2-4 \mathrm{~h}$ to separate the resulting aqueous and organic phases. Both phases were separated and weighed for mass balance computation. In this paper the products produced from hydrocracking the oxidized product and following its separation as an organic fraction will be referred to as the hydrocarbon mixture (HCM). The products produced from hydrocracking the RBO and following its separation as an organic fraction will be referred to as the hydrocarbon mixture from RBO (HCM-RBO). The byproducts produced in this process included water and off-gas.

\section{Data analysis}


The RBO, oxidized product, HCM and HCM-RBO were characterized with ASTM standard

161

162

163

164

165

166

167

168

169

170

171

172

173

174

175

176

177

178 179 spectra were obtained.

180

181 according to ASTM D445.

analysis methods. The HHVs were determined by Ika-5000 bomb calorimeter by ASTM D240.

The acid values (AVs) were determined by dissolving $1 \mathrm{~g}$ of bio-oil in $50 \mathrm{ml}$ of 35:65 ratio of isopropanol to water mixtures and titrating to a $\mathrm{pH}$ of 8.5 with $0.1 \mathrm{~N} \mathrm{KOH}$ solution according to ASTM D664. $\mathrm{pH}$ values were determined by addition of $1 \mathrm{~g}$ of bio-oil to $50 \mathrm{ml}$ of $35 \%$ of isopropanol mixture by ASTM E70. Elemental carbon, hydrogen, and nitrogen were determined by EAI CE-440 elemental analyzer with oxygen content determined by difference according to ASTM D5291. Water content was determined by Karl-Fisher titration by ASTM E203. The densities were determined by Anton Parr DMA 35n portable density meter by ASTM D4052. Viscosities were determined by Ubbelohde capillary viscometer at $40{ }^{\circ} \mathrm{C}$ water bath temperature

The GC-MS analysis of the RBO, HCM and HCM-RBO were performed with a HewlettPackard HP 5890-Series II GC equipped with a Hewlett-Packard HP 5971 series MS. FTIR spectra were obtained by Varian 3500 FTIR analyzer with standard potassium bromide disk technique and spectra were analyzed by Varian-Resolutions software. A mass balance for the mixed hydrocarbons produced by the best performing catalyst was calculated. A detailed hydrocarbon analysis (DHA) of HCM was performed by ASTM D6730-01. Nuclear magnetic resonance spectroscopy (NMR) spectra were collected using a Bruker $600 \mathrm{MHz}$ spectrometer. Each sample was dissolved in chloroform-d $\left(\mathrm{CDCl}_{3}\right.$ as a solvent) and the proton $\left({ }^{1} \mathrm{H}\right) \mathrm{NMR}$

\section{Results and discussion}

\subsection{Pretreatment of the raw bio-oil}


The physical and chemical properties of the RBO and oxidized product are compared in Table 1. As shown in Table 1, following the oxidative pretreatment of RBO the oxidized product AV increased to $162.4 \mathrm{mg} \mathrm{KOH} / \mathrm{g}$ from $90.2 \mathrm{mg} \mathrm{KOH} / \mathrm{g}$ of $\mathrm{RBO}$, an increase of $80.0 \%$. The 15.8 $\mathrm{MJ} / \mathrm{kg} \mathrm{HHV}$ of RBO increased to $16.2 \mathrm{MJ} / \mathrm{kg}$. The water content of the oxidized product increased to $33.3 \mathrm{wt} \%$ from the $30.6 \mathrm{wt} \%$ value of raw bio-oil. The $\mathrm{pH}$ of the oxidized product decreased to 2.6 from the 3.1 of $\mathrm{RBO}$; the $\mathrm{pH}$ decrease was due to increase of acid value of the oxidized product. Oxidized product density decreased from $1.2 \mathrm{~g} / \mathrm{ml}$ for RBO to $1.0 \mathrm{~g} / \mathrm{ml}$. The viscosity of the RBO at $12.2 \mathrm{cSt}$ decreased to $9.4 \mathrm{cSt}$ for the oxidized product.

\subsection{Effect of the reaction temperature on hydrocracking of the oxidized product}

Fig. 1 compares the HHVs, AVs, water contents, oxygen contents and HCM yields of the three hydrocracked oxidized product test samples at three tested reaction temperatures. As shown in Fig. 1, the HHVs of the HCMs produced at the reaction temperatures of 375,400 and $425{ }^{\circ} \mathrm{C}$ were $39.5,40.5$ and $43.6 \mathrm{MJ} / \mathrm{kg}$, respectively. The AVs of the HCMs produced at 375, 400 and $425{ }^{\circ} \mathrm{C}$ were $28.2,12.8$ and $0.3 \mathrm{mg} \mathrm{KOH} / \mathrm{g}$, respectively. The water contents of the HCMs produced were $1.4,0.7$ and $0.5 \mathrm{wt} \%$ for the respective treatment temperatures of 375,400 and $425{ }^{\circ} \mathrm{C}$. The oxygen content of the HCMs produced at 375,400 and $425{ }^{\circ} \mathrm{C}$ were $11.4,8.6$, and $0.5 \mathrm{wt} \%$, respectively. The HCM yields were 16.1, 30.4 and $23.5 \mathrm{wt} \%$ for the respective treatment temperatures of 375,400 and $425^{\circ} \mathrm{C}$.

The HCM produced at the $425{ }^{\circ} \mathrm{C}$ treatment had a $10.4 \%$ higher $\mathrm{HHV}, 98.9 \%$ lower $\mathrm{AV}$, $64.3 \%$ lower water content, $95.6 \%$ less oxygen content and $45.9 \%$ higher yield when compared to the $375{ }^{\circ} \mathrm{C}$ treatment. The $\mathrm{HCM}$ produced at $425^{\circ} \mathrm{C}$ had $7.7 \%$ higher $\mathrm{HHV}, 97.6 \%$ lower $\mathrm{AV}$, $28.6 \%$ lower water content, $94.2 \%$ less oxygen content and $22.7 \%$ higher yield when compared to the $400{ }^{\circ} \mathrm{C}$ treatment. 
Among these three temperatures tested, the hydrocracking reaction performed at $400{ }^{\circ} \mathrm{C}$

produced a higher $\mathrm{HCM}$ yield $(30.4 \mathrm{wt} \%)$ compared to the $375{ }^{\circ} \mathrm{C}(16.1 \mathrm{wt} \%)$ and $425{ }^{\circ} \mathrm{C}(23.5$

wt $\%$ ) treatments. However, the HCM physical and chemical properties produced at $425{ }^{\circ} \mathrm{C}$ (Fig

1) were of considerably higher quality compared to those for the $375{ }^{\circ} \mathrm{C}$ and $400{ }^{\circ} \mathrm{C}$ treatments. Therefore, hydrocracking performed at the reaction temperature of $425{ }^{\circ} \mathrm{C}$ was considered to be the best treatment.

\subsection{Effect of the reaction hydrogen pressure and time on hydrocracking of the oxidized} product

As shown in Table 2, effects of reaction hydrogen pressure and time were investigated by performing the hydrocracking reactions under pressurized hydrogen at 1000, 1200 and 1400 psig. The effect of reaction times of 2.0, 2.5 and $3.0 \mathrm{~h}$ were also tested. The temperature applied was $425{ }^{\circ} \mathrm{C}$ and was found to produce the best HCM properties as discussed above.

Table 2 results show that the HHVs of the HCM produced at the reaction pressures of 1000 , 1200 and 1400 psig were 39.3, 41.9 and 43.6 MJ/kg, respectively. Therefore the HCM produced at the 1400 psig pressurized reaction had $10.9 \%$ and $4.1 \%$ higher HHV compared to those for 1000 and 1200 psig, respectively. The AVs of the HCMs produced at 1000, 1200 and 1400 psig were 3.7, 2.1 and $0.3 \mathrm{mg} \mathrm{KOH} / \mathrm{g}$, respectively. The reduction of AV for the HCM produced at 1400 psig was $91.9 \%$ and $85.7 \%$ more compared to the 1000 and 1200 psig treatments. The water content values for the HCMs were 1.8, 0.9 and $0.5 \mathrm{wt} \%$ for the respective treatment

224 pressures of 1000, 1200 and 1400 psig. The oxygen contents of the HCMs produced at 1000, 2251200 and 1400 psig were 8.7, 3.8 and $0.5 \mathrm{wt} \%$, respectively. The HCM yields for the 1000, 1200 and 1400 psig treatments were approximately the same at 23.5, 24.0 and $23.5 \mathrm{wt} \%$.

Among the three hydrogen pressure conditions tested, the HCM produced at 1400 psig had higher $\mathrm{HHV}$, lower AV, lower water content and lower oxygen content compared to the 1000 
229 and 1200 psig HCM products. Therefore, hydrocracking performed at 1400 psig hydrogen 230 pressure was considered the best treatment.

231 The effects of the reaction time on the hydrocracking of the oxidized product were tested at 232 the previously ascertained most-effective reaction temperature of $425^{\circ} \mathrm{C}$ and 1400 psig hydrogen 233 pressure. The HHVs of the HCMs produced at reaction times 2.0, 2.5 and $3.0 \mathrm{~h}$ were 42.8, 43.6 234 and $44.3 \mathrm{MJ} / \mathrm{kg}$, respectively. The respective AVs of the HCMs produced at 2.0, 2.5 and $3.0 \mathrm{~h}$ 235 were $3.2,0.3$ and $0.3 \mathrm{mg} \mathrm{KOH} / \mathrm{g}$. The water content values of the HCMs were $0.7,0.5$ and 0.4 $236 \mathrm{wt} \%$ for the respective treatment times of 2.0, 2.5 and $3.0 \mathrm{~h}$. The oxygen content values of the 237 HCMs produced at 2.0, 2.5 and $3.0 \mathrm{~h}$ were 3.4, 0.5 and $0.4 \mathrm{wt} \%$, respectively. The HCM yields 238 were 19.0, 23.5 and $20.0 \mathrm{wt} \%$ for the respective treatment times of 2.0, 2.5 and $3.0 \mathrm{~h}$.

239 Among the three reaction times tested, the HCM produced at the $2.5 \mathrm{~h}$ reaction time (yield of $24023.5 \mathrm{wt} \%$ ) had yields $23.7 \%$ and $14.9 \%$ higher compared to those for $2.0(19.0 \mathrm{wt} \%)$ and $3.0 \mathrm{~h}$ 241 (20.0 wt\%), respectively. The AV of the HCM produced at $2.5 \mathrm{~h}(\mathrm{AV}$ of $0.3 \mathrm{mg} \mathrm{KOH} / \mathrm{g}) \mathrm{had}$ the 242 same $\mathrm{AV}$ as for the $3.0 \mathrm{~h}$ reaction ( $\mathrm{AV}$ of $0.3 \mathrm{mg} \mathrm{KOH} / \mathrm{g}$ ) and was $90.6 \%$ lower compared to that 243 of the $2.0 \mathrm{~h}$ reaction ( $\mathrm{AV}$ of $3.2 \mathrm{mg} \mathrm{KOH} / \mathrm{g})$. The oxygen content of the HCM produced at $2.5 \mathrm{~h}$ 244 (oxygen content of $0.5 \mathrm{wt} \%$ ) was $85.3 \%$ lower compared to the $2.0 \mathrm{~h}$ reaction (oxygen content of $2453.4 \mathrm{wt} \%$ ); the HCM produced at $3.0 \mathrm{~h}$ had approximately the same oxygen content. Therefore, 246 hydrocracking performed at the $2.5 \mathrm{~h}$ reaction time produced an HCM with the highest yield and 247 best property qualities and was considered as the best treatment.

248 In summary, the hydrocracking of the oxidized product reaction performed at a reaction 249 temperature of $425{ }^{\circ} \mathrm{C}$ under hydrogen pressurized of $1400 \mathrm{psig}$ with a reaction time of $2.5 \mathrm{~h}$ was 250 considered to be optimal. At these optimal reaction conditions the effects of the various 
251 commercial catalysts were tested by following the hydrocracking procedure described in section $252 \quad 2.2$

\subsection{Effect of catalyst type on hydrocracking of the oxidized product}

The efficacy of the hydrocracking of the oxidized product at our selected optimal reaction conditions was tested by performing the reaction in the presence of various commercially available catalysts. Fig. 2 shows the comparison of the HHVs and AVs of the HCMs produced using $\mathrm{Ni} / \mathrm{SiO}_{2}-\mathrm{Al}_{2} \mathrm{O}_{3}, \mathrm{Ni} / \mathrm{SiO}_{2}-\mathrm{Al}_{2} \mathrm{O}_{3}+\mathrm{CuO}, \mathrm{Ru} / \mathrm{C}+\mathrm{CuO}$ and $\mathrm{Ru} / \mathrm{Al}_{2} \mathrm{O}_{3}+\mathrm{CuO}$ as catalysts via direct hydrocracking of the oxidized product. The HHVs of the $\mathrm{HCMs}$ produced using $\mathrm{Ni} / \mathrm{SiO}_{2}-$ $\mathrm{MJ} / \mathrm{kg}$, respectively. The $\mathrm{AVs}$ of the $\mathrm{HCMs}$ produced using $\mathrm{Ni} / \mathrm{SiO}_{2}-\mathrm{Al}_{2} \mathrm{O}_{3}, \mathrm{Ni} / \mathrm{SiO}_{2}$ $\mathrm{Al}_{2} \mathrm{O}_{3}+\mathrm{CuO}, \mathrm{Ru} / \mathrm{C}+\mathrm{CuO}$ and $\mathrm{Ru} / \mathrm{Al}_{2} \mathrm{O}_{3}+\mathrm{CuO}$ were $0.5,0.3,0.1$ and $9.4 \mathrm{mg} \mathrm{KOH} / \mathrm{g}$, respectively.

Fig. 3 compares the HCM yield, oxygen content and water content of the hydrocracking of 266 the oxidized product reaction performed using $\mathrm{Ni} / \mathrm{SiO}_{2}-\mathrm{Al}_{2} \mathrm{O}_{3}, \mathrm{Ni} / \mathrm{SiO}_{2}-\mathrm{Al}_{2} \mathrm{O}_{3}+\mathrm{CuO}, \mathrm{Ru} / \mathrm{C}+\mathrm{CuO}$ 267 and $\mathrm{Ru} / \mathrm{Al}_{2} \mathrm{O}_{3}+\mathrm{CuO}$ as catalysts. As shown in Fig. 3, the $\mathrm{HCM}$ yields for the $\mathrm{Ni} / \mathrm{SiO}_{2}-\mathrm{Al}_{2} \mathrm{O}_{3}$,

$268 \mathrm{Ni} / \mathrm{SiO}_{2}-\mathrm{Al}_{2} \mathrm{O}_{3}+\mathrm{CuO}, \mathrm{Ru} / \mathrm{C}+\mathrm{CuO}$ and $\mathrm{Ru} / \mathrm{Al}_{2} \mathrm{O}_{3}+\mathrm{CuO}$ as catalyst were 20.6, 23.5, 15.0 and 18.4 $269 \mathrm{wt} \%$, respectively. The oxygen contents were $0.2,0.5,6.3$ and $11.3 \mathrm{wt} \%$ for the HCMs produced 270 using the respective $\mathrm{Ni} / \mathrm{SiO}_{2}-\mathrm{Al}_{2} \mathrm{O}_{3}, \mathrm{Ni} / \mathrm{SiO}_{2}-\mathrm{Al}_{2} \mathrm{O}_{3}+\mathrm{CuO}, \mathrm{Ru} / \mathrm{C}+\mathrm{CuO}$ and $\mathrm{Ru} / \mathrm{Al}_{2} \mathrm{O}_{3}+\mathrm{CuO}$ 271 catalysts. The water contents of the $\mathrm{HCMs}$ produced using $\mathrm{Ni} / \mathrm{SiO}_{2}-\mathrm{Al}_{2} \mathrm{O}_{3}, \mathrm{Ni} / \mathrm{SiO}_{2}-\mathrm{Al}_{2} \mathrm{O}_{3}+\mathrm{CuO}$, $272 \mathrm{Ru} / \mathrm{C}+\mathrm{CuO}$ and $\mathrm{Ru} / \mathrm{Al}_{2} \mathrm{O}_{3}+\mathrm{CuO}$ catalysts were $0.8,0.5,2.9$ and $3.6 \mathrm{wt} \%$, respectively. The $\mathrm{HCM}$ 273 produced using $\mathrm{Ni} / \mathrm{SiO}_{2}-\mathrm{Al}_{2} \mathrm{O}_{3}+\mathrm{CuO}$ catalyst had $14.1 \%, 36.2 \%$ and $21.7 \%$ higher $\mathrm{HCM}$ yield 
274 compared to the $\mathrm{Ni} / \mathrm{SiO}_{2}-\mathrm{Al}_{2} \mathrm{O}_{3}, \mathrm{Ru} / \mathrm{C}+\mathrm{CuO}$ and $\mathrm{Ru} / \mathrm{Al}_{2} \mathrm{O}_{3}+\mathrm{CuO}$ catalysts, respectively.

275 Therefore, the $\mathrm{HCM}$ produced using $\mathrm{Ni} / \mathrm{SiO}_{2}-\mathrm{Al}_{2} \mathrm{O}_{3}+\mathrm{CuO}$ as catalyst produced with better

276 quality $\mathrm{HCM}$ fuel compared to the $\mathrm{Ni} / \mathrm{SiO}_{2}-\mathrm{Al}_{2} \mathrm{O}_{3}, \mathrm{Ru} / \mathrm{C}+\mathrm{CuO}$ and $\mathrm{Ru} / \mathrm{Al}_{2} \mathrm{O}_{3}+\mathrm{CuO}$ as catalysts.

277 The addition of $\mathrm{CuO}$ to $\mathrm{Ni} / \mathrm{SiO}_{2}-\mathrm{Al}_{2} \mathrm{O}_{3}$ increased fuel properties and yields compared to $\mathrm{Ni} / \mathrm{SiO}_{2}-$

$278 \mathrm{Al}_{2} \mathrm{O}_{3}$ alone. It was well known Ni-based catalysts promote hydrogenation of bio-oil but here

279 addition of $\mathrm{CuO}$ might have also promoted other decarboxylation or decarbonylation or

280 deoxygenation type reactions along with hydrogenation. Therefore hydrocracking was taken

281 place better than other catalysts and fuel properties were found best for this combination.

282

283

$284 \quad$ 5. FTIR analysis

285

Fig. 4 shows the comparison of RBO and HCM FTIR spectra. These spectra analyze the

286 functional groups present in the product types. Characteristic vibrational modes were observed at $2873200-3600 \mathrm{~cm}^{-1}$ (OH stretch), 2800-3050 $\mathrm{cm}^{-1}\left(\mathrm{CH}\right.$ aliphatic stretch), 1600-1750 $\mathrm{cm}^{-1}(\mathrm{C}=\mathrm{O}$ 288 stretch), 1350-1470 $\mathrm{cm}^{-1}$ (CH bending) and 1000-1250 $\mathrm{cm}^{-1}$ (C-O stretch). As shown in Fig. 4, it 289 is clear that the very broad $\mathrm{OH}$ stretching absorption peak present in the RBO spectrum 290 completely disappeared in the HCM spectrum. The $\mathrm{CH}$ aliphatic stretch absorption band at 2800$2913050 \mathrm{~cm}^{-1}$ in the HCM spectrum dramatically increased compared to the RBO spectrum. The $292 \mathrm{C}=\mathrm{O}$ absorption band of carbonyl functional group and the $\mathrm{C}-\mathrm{O}$ absorption band of ether, alcohol 293 functional groups were reduced in the HCM spectrum compared to the RBO spectrum. The 294 change in the FTIR spectrum of HCM from RBO spectrum absorption bands indicated that the 295 carboxylic acids, aldehydes and other oxygenated chemical compounds were converted into 296 hydrocarbons. 


\section{GC-MS analysis}

Table 3 shows the chemical composition of RBO and HCM identified by GC-MS. Approximately 50 major chemical compounds were analyzed by GC-MS in both samples. The chemical compound name and their area percentages are given in Table 3. The total area percentages of the major fifty compounds present in RBO and HCM were $100.0 \%$ and $99.9 \%$, respectively. As shown in Table 3 there was a considerable change in the chemical composition and area\% the of the RBO as compared to the HCM produced by direct hydrocracking of the oxidized product at the selected optimum reaction conditions (reaction temperature of $425{ }^{\circ} \mathrm{C}$, hydrogen pressure of $1400 \mathrm{psig}$, reaction time of $2.5 \mathrm{~h}, \mathrm{Ni} / \mathrm{SiO}_{2}-\mathrm{Al}_{2} \mathrm{O}_{3}+\mathrm{CuO}$ as the catalyst). The 9.8 area $\%$ of carboxylic acids, 12.1 area $\%$ of esters-ethers, 35.9 area $\%$ of aldehydes-ketones,

38.3 area\% of alcohols-phenols and 2.1 area\% of other RBO compounds were nearly $100 \%$ converted to hydrocarbon compounds via direct hydrocracking of the oxidized product. The HCM was comprised of approximately 99.2 area\% of hydrocarbon compounds.

\section{DHA analysis}

A DHA was performed by ASTM D6730-01 on the HCM produced at the optimum conditions. The DHA test is often referred to the as PIANO method (paraffins, iso-paraffins, aromatics, naphthenes and olefins) to classify the hydrocarbons present in the hydrocarbon

314 mixture. The DHA results are given in Table 4. These results show that the hydrocarbon mixture 315 contained n-paraffins of 0.6 mass $\%$, iso-paraffins of 23.7 mass $\%$, olefins of 26.1 mass $\%$, 316 naphthenes of 8.2 mass $\%$, aromatics of 5.8 mass $\%$, total C14+ of 6.2 mass $\%$ and unknown 317 compounds of 17.9 mass\%. This DHA analysis also calculated the liquid hydrocarbon mixture 318 octane number as 58.6 and average molecular weight was computed to be 110.75 .

\section{Direct hydrocracking of RBO and oxidized product}


As a control, the RBO was also tested by application of the direct hydrocracking treatment at

321

322

323

324

325

326

327

328

329

330

331

332

333

334

335

336

337

338

339

340

341

342

the optimal reaction conditions using $\mathrm{Ni} / \mathrm{SiO}_{2}-\mathrm{Al}_{2} \mathrm{O}_{3}+\mathrm{CuO}$ as catalyst and its $\mathrm{HCM}-\mathrm{RBO}$ was compared with the HCM produced from the oxidized product. Fig. 5 compares the HHVs, AVs, water content, oxygen content and yields of both HCM and HCM-RBO. The HHVs of the HCMRBO and HCM were 40.8 and $43.6 \mathrm{MJ} / \mathrm{kg}$, respectively. The HCM had $6.9 \%$ higher $\mathrm{HHV}$ compared to the HCM-RBO. The AV of the HCM was $0.3 \mathrm{mg} \mathrm{KOH} / \mathrm{g}$ compared to $1.4 \mathrm{mg}$ $\mathrm{KOH} / \mathrm{g}$ for the HCM-RBO, a reduction of $78.6 \%$. The water content of the HCM-RBO and HCM were 0.9 and $0.7 \mathrm{wt} \%$, respectively. The oxygen content of the HCM-RBO and HCM were 2.3 and $0.2 \mathrm{wt} \%$, respectively. The HCM had $91.3 \%$ lower oxygen content compared to the HCM-RBO. The yield of HCM was $23.5 \mathrm{wt} \%$ compared to $17.2 \mathrm{wt} \%$ for the HCM-RBO. Hydrocracking of the oxidized product produced $36.6 \%$ higher HCM yield compared to the direct hydrocracking of the RBO. These results show that the oxidized product, when directly hydrocracked, produces both high quality and yields compared to RBO.

\section{9. ${ }^{1} \mathrm{H}-\mathrm{NMR}$ spectroscopic analysis}

Proton $\left({ }^{1} \mathrm{H}\right)$ NMR spectra of the RBO (a), HCM-RBO (b) and HCM (c) are shown in Fig 6. As shown in Fig, 6 (a), (b) and (c) it is evident that there is a large difference between ${ }^{1} \mathrm{H}-\mathrm{NMR}$ spectrum of the RBO, HCM-RBO and HCM. The RBO spectrum shown in Fig. 6(a) is very complex and consists of a large number of proton signals due to the presence of various oxygenated compounds with differing functional groups.

Comparison of the Fig. 6(a) spectra of RBO to the HCM-RBO in Fig. 6(b) shows that the oxygenated compounds' proton signals at a chemical shift of 2.0-2.8 ppm (acyl, benzylic and aliphatic hydroxyl functional groups) and proton signals with chemical shift from 3.2-5.2 ppm (esters, ethers, lignin derived methoxy phenols) were not completely eliminated. This indicates 
343 that some of the oxygenated compounds present in the RBO were not deoxygenated or may not

344 be fully converted to hydrocarbons during the hydrocracking of the RBO.

345 Comparing the Fig. 6(a) spectra of RBO and Fig. 6(c) spectra of HCM shows that the proton 346 signals at a chemical shift of 2.0-2.8 and 3.2-5.2 ppm were reduced considerably due to the 347 higher conversion of oxygenated compounds present in the oxidized product. In the HCM 348 product spectra the aliphatic hydrocarbons' proton signals, with an up-field chemical shift of 0.8$3491.9 \mathrm{ppm}$ were higher than HCM-RBO. The HCM spectrum's number of proton signals reduced 350 considerably compared to the HCM-RBO spectrum. This indicates that oxidation pretreatment 351 followed by direct hydrocracking of the oxidized product resulted in conversion of a high 352 percentage of oxygenated compounds to hydrocarbons compared to the direct hydrocracking of 353 the RBO.

354 10. Conclusions

355 The direct hydrocracking of oxidized bio-oil produced liquid hydrocarbons of transportation 356 fuel quality. The optimum reaction conditions were found to be a reaction temperature of $425{ }^{\circ} \mathrm{C}$ 357 under hydrogen pressure of 1400 psig for $2.5 \mathrm{~h}$. $\mathrm{Ni} / \mathrm{SiO}_{2}-\mathrm{Al}_{2} \mathrm{O}_{3}+\mathrm{CuO}$ was the best catalyst. 358 Hydrocracking of the oxidized product produced 36.6\% higher HCM yield compared to 359 hydrocracking of the RBO. The HCM had 6.9\% higher HHV compared to the HCM-RBO. The 360 HCM had $91.3 \%$ lower oxygen content compared to the HCM-RBO. The AV of the HCM was $3610.3 \mathrm{mg} \mathrm{KOH} / \mathrm{g}$ compared to $1.4 \mathrm{mg} \mathrm{KOH} / \mathrm{g}$ for the $\mathrm{HCM}-\mathrm{RBO}$, a reduction of $78.6 \%$.

\section{Acknowledgements}

363 This research was performed based upon work funded through the Sustainable Energy 364 Research Center at Mississippi State University (MSU) and is supported by the Department of 365 Energy under Award Number DE-FG3606G086025. We also thank B. K. Mitchell of the 
Department of Forest Products, MSU, for his assistance in the production of bio-oil by fast pyrolysis.

\section{Disclaimer}

This report was prepared as an account of work sponsored by an agency of the United States government. Neither the United States Government nor any agency thereof, nor any of their employees, makes any warranty, express or implied, or assumes any legal liability or responsibility for the accuracy, completeness, or usefulness of any information, apparatus, product, or process disclosed, or represents that its use would not infringe privately owned rights. Reference herein to any specific commercial product, process, or service by trade name, trademark, manufacturer, or otherwise does not necessarily constitute or imply its endorsement, recommendation, or favoring by the United States Government or any agency thereof. The views and opinions of authors expressed herein do not necessarily state or reflect those of the United States Government or any agency thereof.

\section{References}

1. Perlack RD, Stokes, BJ. U.S. Billion-Ton Update: Biomass Supply for a Bioenergy and Bioproducts Industry. ORNL/TM-2011/224. U.S. Department of Energy. Oak Ridge National Laboratory, Oak Ridge, TN. 2011, 227p.

2. Yan J, Alvors P, Eidensten L. A future for biomass: Mechanical Engineering 1997;117, 94-98.

3. Mckendry P. Energy production from biomass (Part 1): Overview of biomass. Bioresour. Technol 2002;1, 37-46.

4. Huber GW, Iborra S, Corma A. Synthesis of transportation fuels from biomass: Chem. Catal. Eng. Chem. Rev 2006;106, 4044-4098. 
5. Ingram Jr L, Mohan D, Bricka M, Steele PH, Strobel D, Crocker D, Mitchell B, Mohammad J, Cantrell K, Pittman Jr CU. Pyrolysis of wood and bark in an auger reactor: physical properties and chemical analysis of the produced bio-oils. Energy Fuels 2008;22, 614-625.

6. Mohan D, Pittman Jr CU, Steele PH. Pyrolysis of wood-biomass for bio-oil: a critical review. Energy Fuels 2006;20, 848-889.

7. Bridgwater AV, Meier D, Radlein D. An overview of fast pyrolysis of biomass. Org. Geochem 1999;30, 1479-1493.

8. Czernik S, Bridgwater AV. Overview of applications of biomass fast pyrolysis oil. Energy Fuels 2004;18, 590-598.

9. Oasmaa A, Elliott DC, Korhonen, J. Acidity of biomass fast pyrolysis bio-oils. Energy Fuels 2010;24, 6548-6554.

10. Peng J, Chen P, Lou H, Zheng X. Catalytic upgrading of bio-oil by HZSM-5 in sub- and super-critical ethanol. Bioresour. Technol 2009;100, 3415-3418.

11. Choudhary TV, Phillips CB. Renewable fuels via catalytic hydrodeoxygenation. Appl. Catal. A: Gen 2011;397, 1-12.

12. Elliott DC. Historical developments in hydroprocessing bio-oils. Energy Fuels 2007;21, 1792-1815.

13. Senol OI, Viljava TR, Krause AOI. Hydrodeoxygenation of methyl esters on sulphided NiMo/[gamma]-Al2O3 and CoMo/[gamma]-Al2O3 catalysts. Catal. Today 2005;100, $331-335$.

14. Bu Q, Lei H, Zacher AH, Wang L, Ren S, Liang J, Wei Y, Liu Y, Tang J, Zhang Q, Ruan R. A review of catalytic hydrodeoxygenation of lignin-derived phenols form biomass 
pyrolysis. Bioresour. Technol 2012;124, 470-477.

15. Wildschut J, Melian CI, Heeres HJ. Catalyst studies on the hydrotreatment of fast pyrolysis oil. Appl. Catal. B: Environ 2010;99, 298-306.

16. De Miguel Mercader F, Groeneveld MJ, Kersten SRA, Way NWJ, Schaverien CJ, Hogendoorn JA. Production of advanced biofuels: Co-processing of upgraded pyrolysis oil in standard refinery units. Appl. Catal. B: Environ 2010;96, 57-66.

17. Tanneru SK, Steele PH. Pretreating bio-oil to increase yield and reduce char during hydrodeoxygenation to produce hydrocarbons. Fuel 2014;133, 326-331.

18. Xu X, Zhang YL, Zhai Y, Zhang R. Two-step catalytic hydrodeoxygenation of fast pyrolysis oil to hydrocarbon liquid fuels. Chemosphere 2013;93, 652-660.

19. Elliott DC, Baker EG. Process for upgrading biomass pyrolyzates. U.S. Pat. 4,795,841, 1989.

20. Wildschut J, Mahfud FH, Venderbosch RH, Heeres HJ. Hydrotreatment of fast pyrolysis oil using heterogeneous noble-metal catalysts. Ind. Eng. Chem. Res 2009;48, 1032410334.

21. McCall MJ, Brandvold TA, Elliott DC. Fuel and fuel blending components from biomass derived pyrolysis oil. U.S. Pat. 8,329,969 B2, 2012.

22. Zhang SP, Yan YJ, Ren Z, Li T. Study of hydrodeoxygenation of bio-oil from the fast pyrolysis of biomass. Energy Sources 2003;3, 57-65

23. Elliott DC, Hart TR, Neuenschwander GG, Rotness L, Olarte MV, Zacher AH, Solantausta Y. Catalytic hydroprocessing of fast pyrolysis bio-oil from pine sawdust. Energy Fuels 2012;26, 3891-3896.

24. Steele PH, Tanneru SK, Gajjela SK. Composition and methods for improved fuel 
production. U.S. Pat. 0291431 A1, 2013.

436

25. Ahmad MM, Fitrir M, Nordin R, Azizan MT. Upgrading of bio-oil into high-value hydrocarbons via hydrodeoxygenation. Am. J. Appl. Sci 2010;7, 746-755.

438

439 
Table 1. Comparison of the RBO and oxidized product physical and chemical properties.

\begin{tabular}{|c|c|c|}
\hline Properties & RBO & Oxidized product \\
\hline Acid value, mg KOH/g & 90.2 & 162.4 \\
\hline $\mathrm{HHV}, \mathrm{MJ} / \mathrm{kg}$ & 15.8 & 16.2 \\
\hline Water content, wt\% & 30.6 & 33.3 \\
\hline $\mathrm{pH}$ & 3.1 & 2.6 \\
\hline Density, g/ml & 1.2 & 1.0 \\
\hline Viscosity, cSt & 12.2 & 9.4 \\
\hline
\end{tabular}


Table 2. Comparison of the HCM HHVs, AVs, water content, oxygen content and yields at the reaction temperature of $425{ }^{\circ} \mathrm{C}$ for the three test hydrogen pressures.

\begin{tabular}{|c|c|c|c|c|c|}
\hline TEST & $\begin{array}{c}\text { HHV } \\
(\mathrm{MJ} / \mathrm{kg})\end{array}$ & $\begin{array}{c}\mathrm{AV} \\
(\mathrm{mg} \mathrm{KOH} / \mathrm{g})\end{array}$ & $\begin{array}{c}\text { Water content } \\
(\mathrm{wt} \%)\end{array}$ & $\begin{array}{c}\text { Oxygen content } \\
(\mathrm{wt} \%)\end{array}$ & $\mathrm{HCM}(\mathrm{wt} \%)$ \\
\hline \multicolumn{6}{|c|}{ Effect of pressure } \\
\hline 1000 Psig & 39.3 & 3.7 & 1.8 & 8.7 & 23.5 \\
\hline 1200 Psig & 41.9 & 2.1 & 0.9 & 3.8 & 24.0 \\
\hline 1400 Psig & 43.6 & 0.3 & 0.5 & 0.5 & 23.5 \\
\hline \multicolumn{6}{|c|}{ Effect of time } \\
\hline $2.0 \mathrm{~h}$ & 42.8 & 3.2 & 0.7 & 3.4 & 19.0 \\
\hline $2.5 \mathrm{~h}$ & 43.6 & 0.3 & 0.5 & 0.5 & 23.5 \\
\hline $3.0 \mathrm{~h}$ & 44.3 & 0.3 & 0.4 & 0.4 & 20.0 \\
\hline
\end{tabular}


Table 3. RBO and HCM chemical composition analysis by GC-MS with area percentages.

\begin{tabular}{|c|c|c|c|}
\hline Raw bio-oil & & HCM & \\
\hline Compound name & Area\% & Compound name & Area \% \\
\hline Carboxylic acids & 9.77 & Hydrocarbons & 99.2 \\
\hline Esters \& Ethers & 12.1 & Other & 0.79 \\
\hline Aldehydes \& Ketones & 35.86 & Total & \\
\hline Alcohols & 39.3 & & \\
\hline Other & 2.1 & & \\
\hline Total & 99.05 & & \\
\hline
\end{tabular}

Table 4. Hydrocarbon types and their mass\% present in HCM results analyzed by DHA ASTM D6730-01.

\begin{tabular}{|c|c|}
\hline Hydrocarbon type & Total mass\% \\
\hline Paraffins & 0.6 \\
\hline Iso-paraffins & 23.7 \\
\hline Olefins & 26.1 \\
\hline Napthens & 8.2 \\
\hline Aromatics & 5.8 \\
\hline Total C14+ & 6.2 \\
\hline Unknowns & 17.9 \\
\hline Octane number & 58.6 \\
\hline Average molecular weight & 110.7 \\
\hline
\end{tabular}




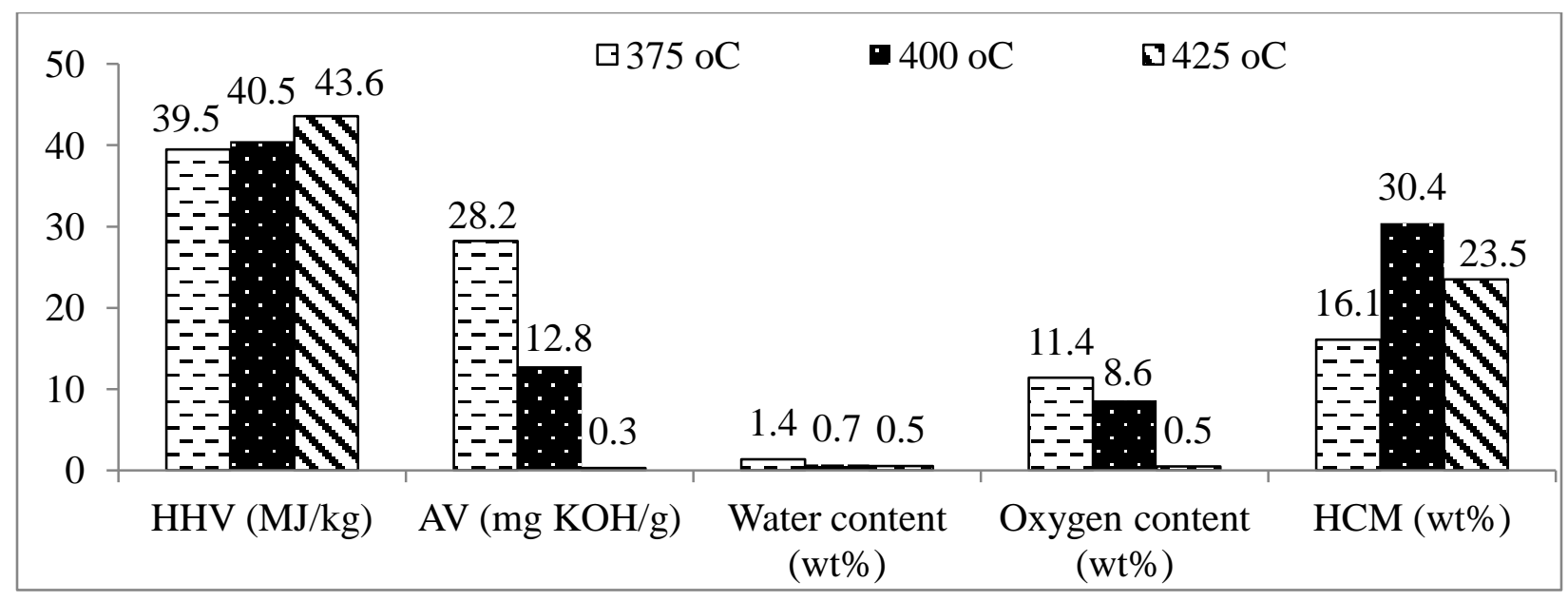

Fig. 1. Comparison of HHVs, AVs, water content, oxygen content and HCM yields of the HCMs produced by the three hydrocracking runs at the reaction temperatures of 375,400 and $425{ }^{\circ} \mathrm{C}$. 


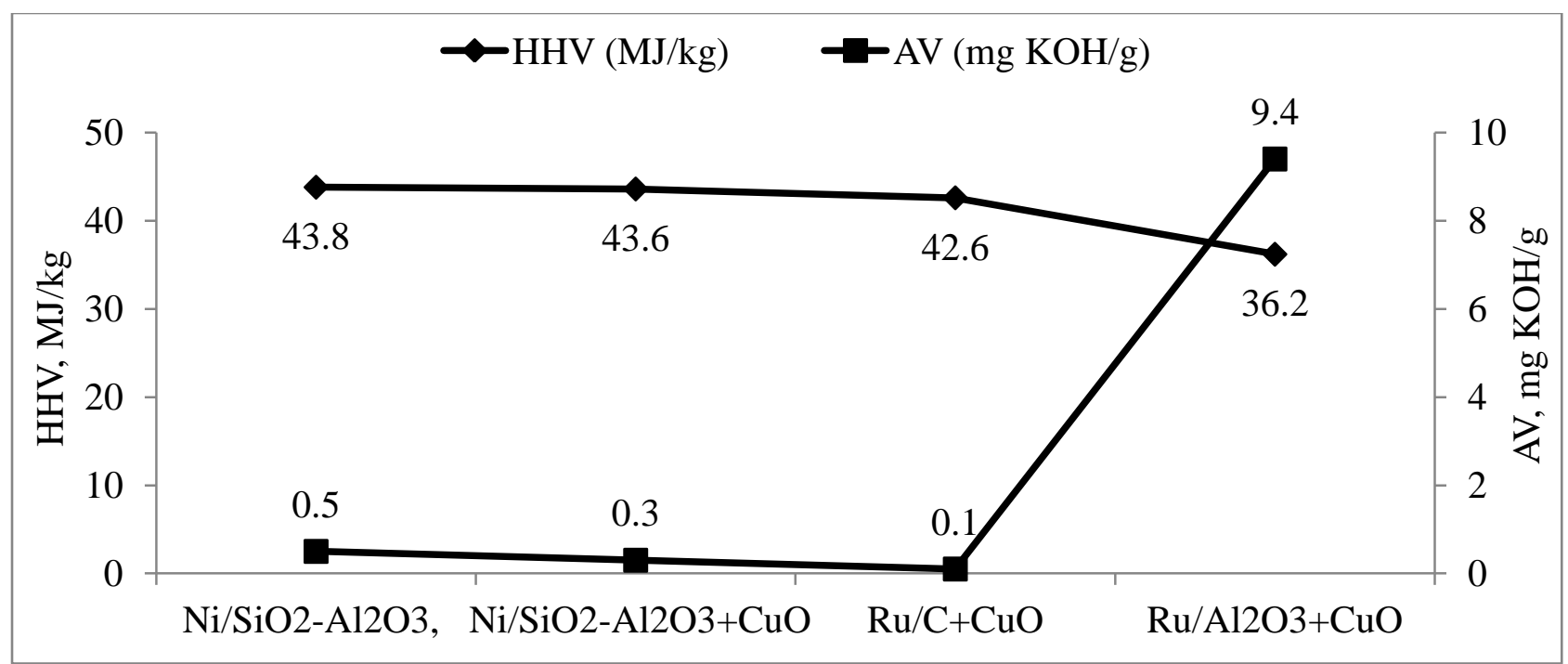

Fig. 2. Comparison of the HHVs and $\mathrm{AVs}$ of the $\mathrm{HCMs}$ produced using $\mathrm{Ni} / \mathrm{SiO}_{2}-\mathrm{Al}_{2} \mathrm{O}_{3}, \mathrm{Ni} / \mathrm{SiO}_{2}$ $\mathrm{Al}_{2} \mathrm{O}_{3}+\mathrm{CuO}, \mathrm{Ru} / \mathrm{C}+\mathrm{CuO}$ and $\mathrm{Ru} / \mathrm{Al}_{2} \mathrm{O}_{3}+\mathrm{CuO}$ as catalysts via direct hydrocracking of the oxidized product reaction. 


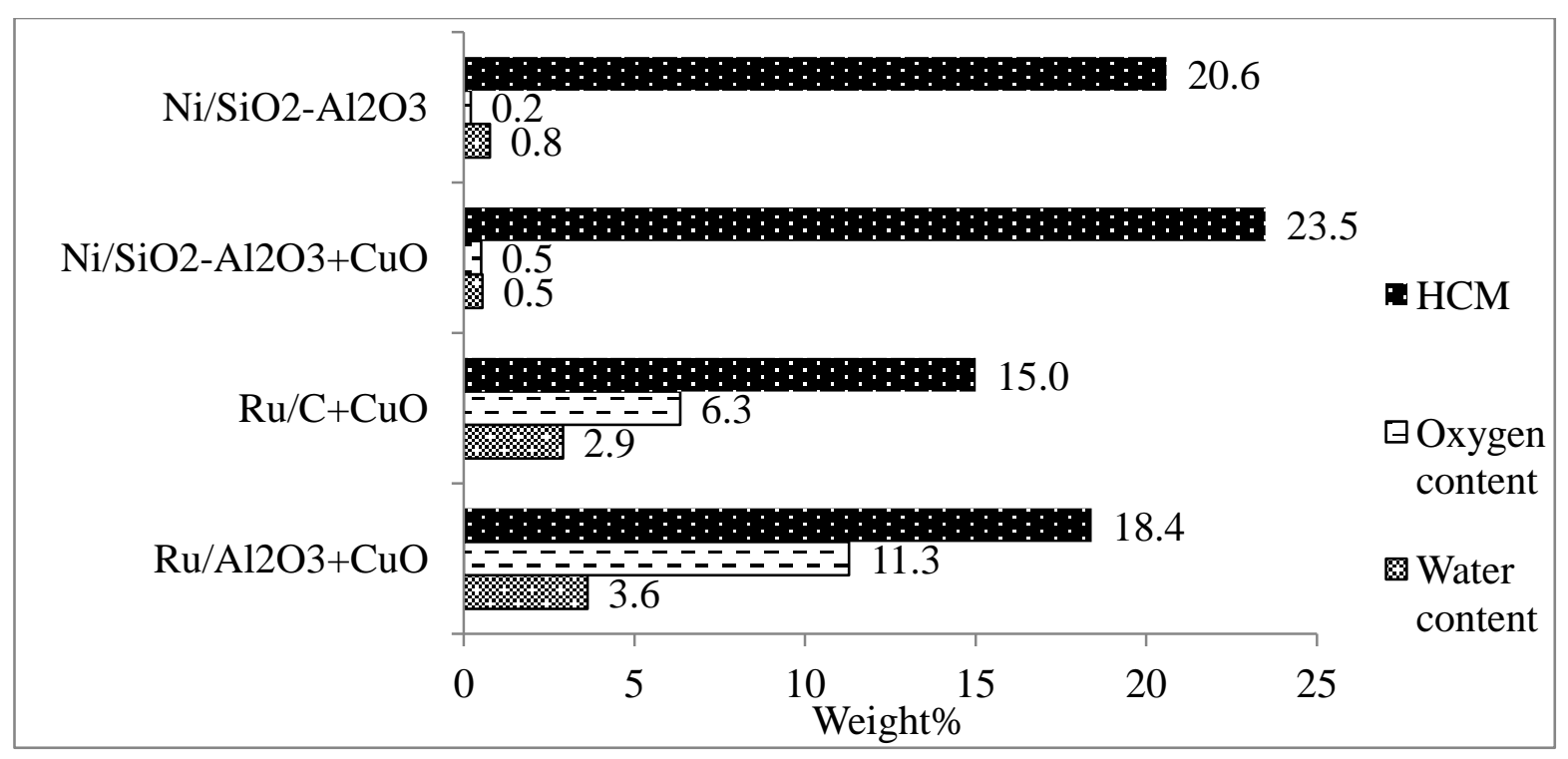

Fig. 3. $\mathrm{HCM}$ yield, oxygen content and water content comparison for $\mathrm{Ni} / \mathrm{SiO}_{2}-\mathrm{Al}_{2} \mathrm{O}_{3}, \mathrm{Ni} / \mathrm{SiO}_{2}$ $\mathrm{Al}_{2} \mathrm{O}_{3}+\mathrm{CuO}, \mathrm{Ru} / \mathrm{C}+\mathrm{CuO}$ and $\mathrm{Ru} / \mathrm{Al}_{2} \mathrm{O}_{3}+\mathrm{CuO}$ catalysts. 


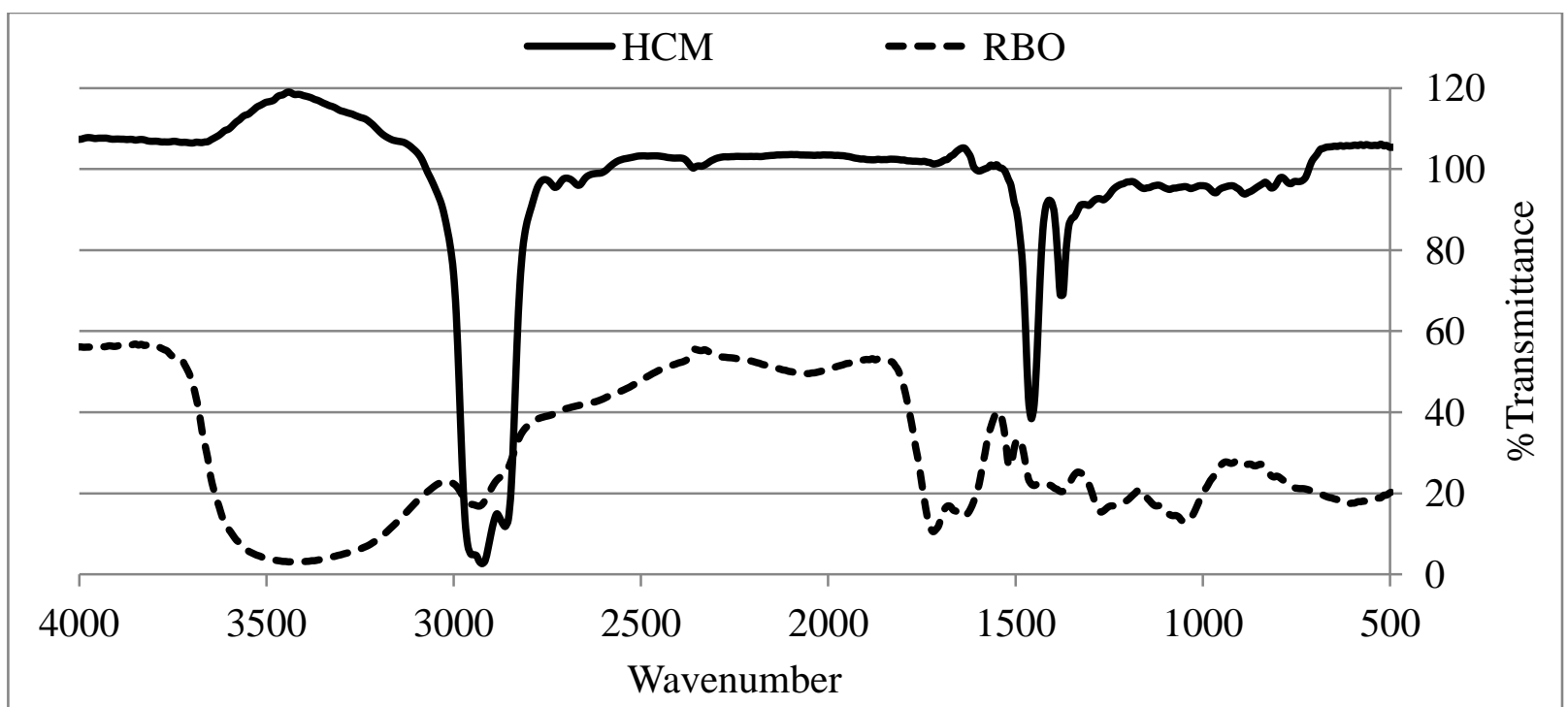

Fig. 4. FTIR spectra comparing raw bio-oil, pretreated-hydrotreated product and hydrocarbon mixture. 


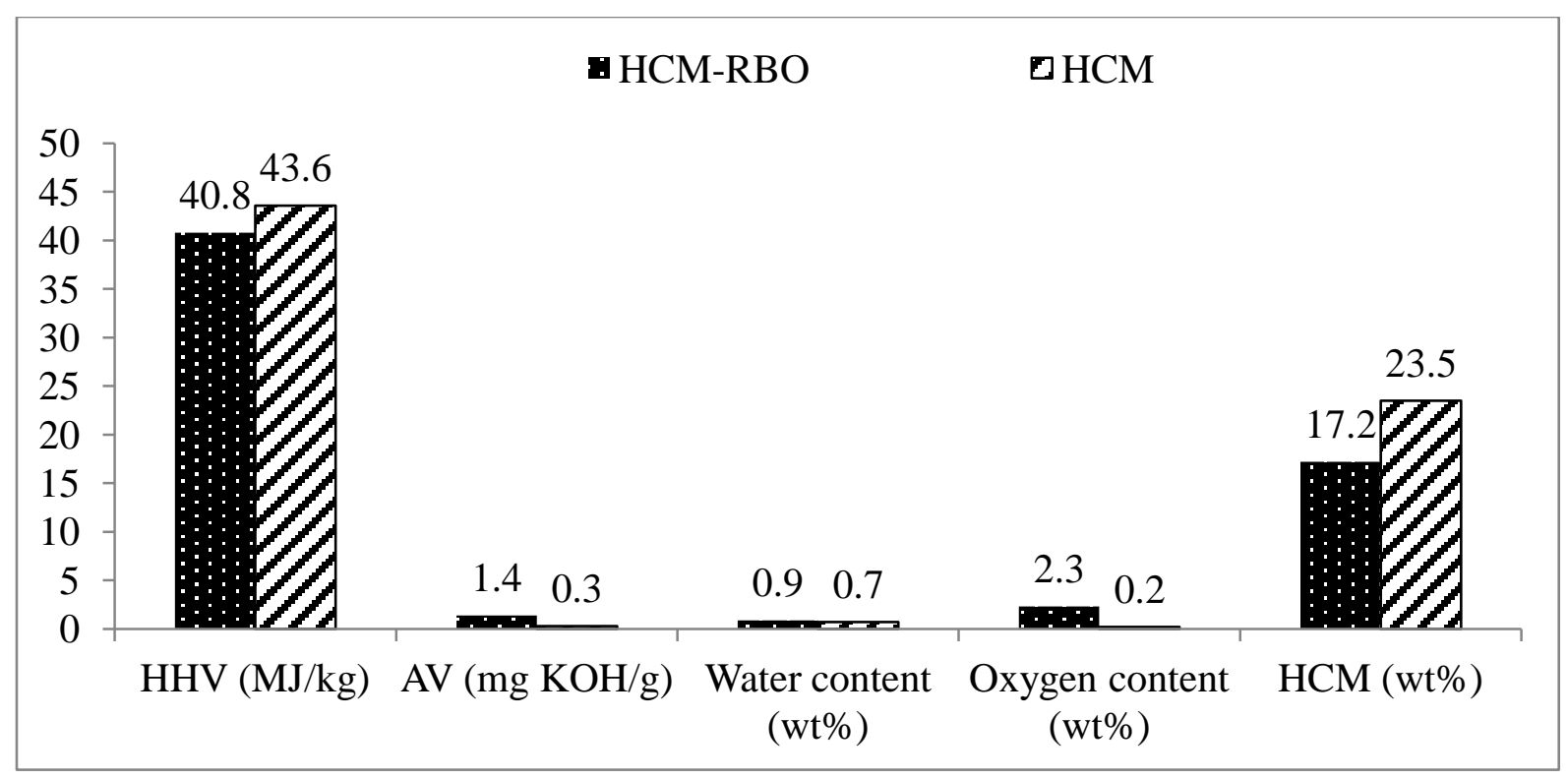

Fig. 5. Comparison of HHVs, AVs, water content, oxygen content and HCM and HCM-RBO yields of the direct hydrocracking of both $\mathrm{RBO}$ and oxidized product at the optimal reaction conditions using $\mathrm{Ni} / \mathrm{SiO}_{2}-\mathrm{Al}_{2} \mathrm{O}_{3}+\mathrm{CuO}$ as catalyst. 


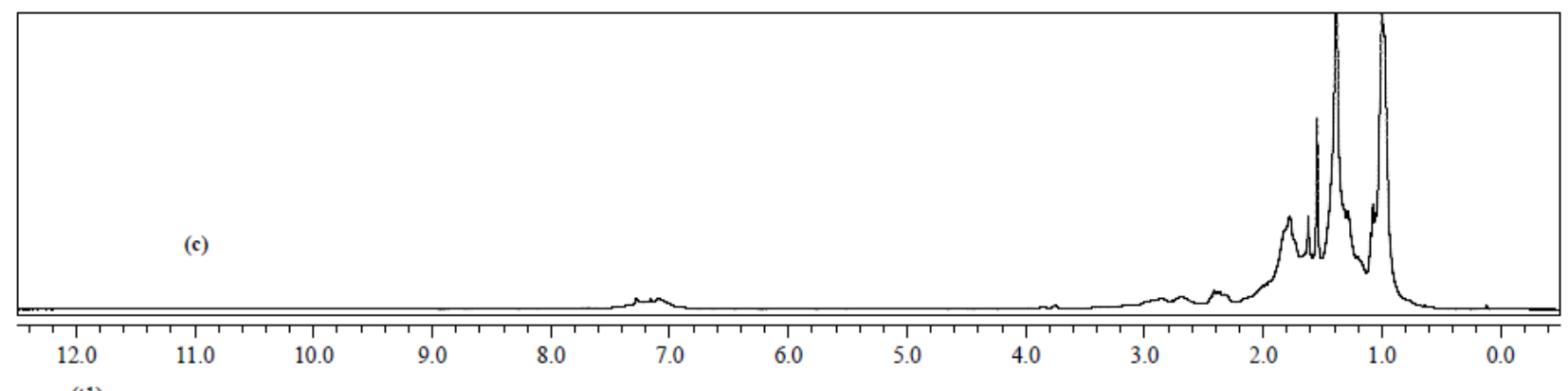

ppm (t1)

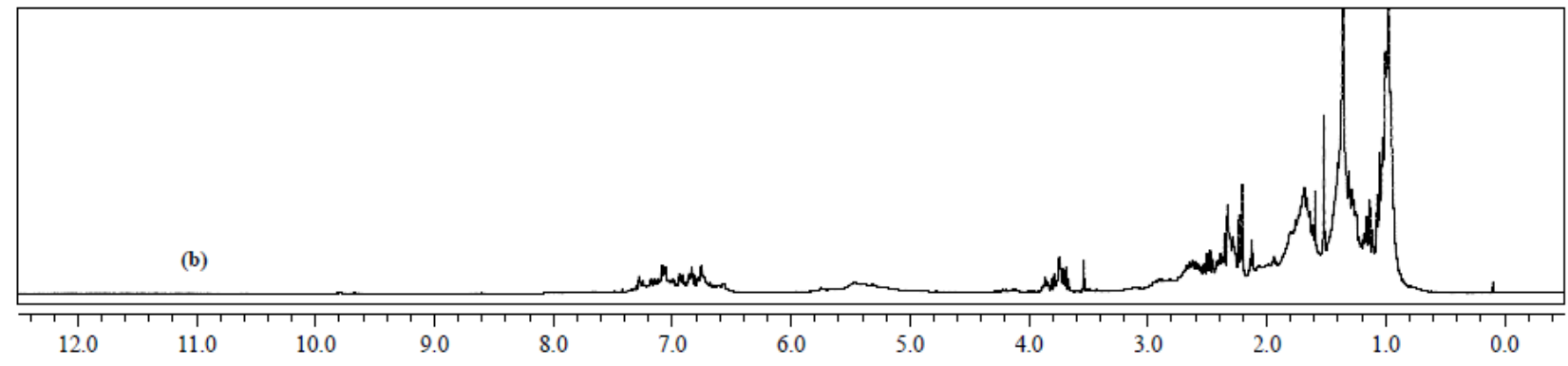

ppm (t1)

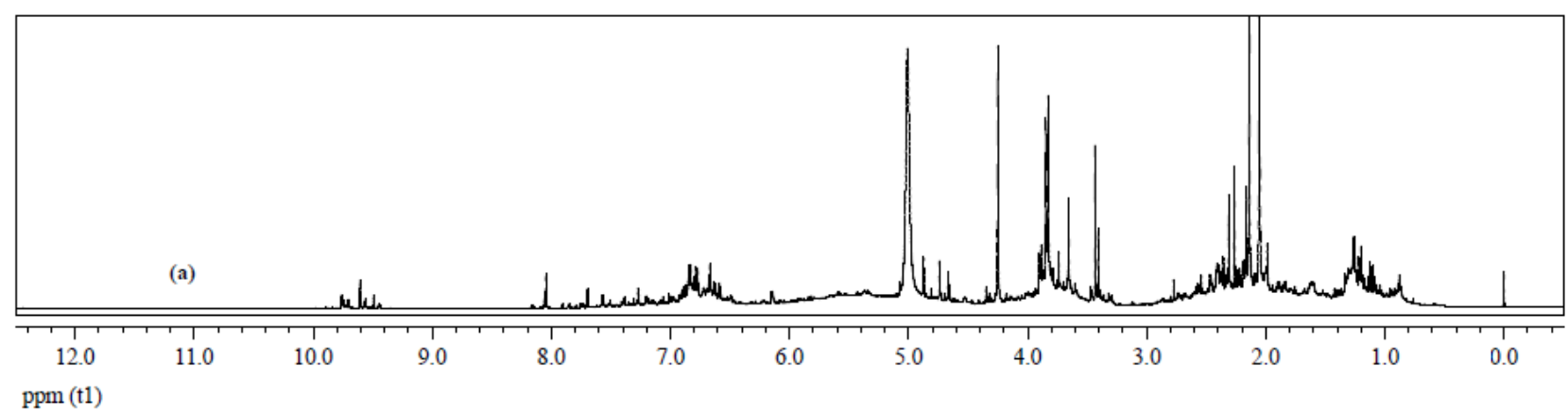

Fig. 6. ${ }^{1} \mathrm{H}-\mathrm{NMR}$ spectra analysis of RBO (a), HCM-RBO (b) and HCM (c) 